\section{Survival, Frost Susceptibility, Growth, and Disease Resistance of Corkbark and Subalpine Fir Grown for Landscape and Christmas Trees}

\author{
Danny L. Barney ${ }^{1,4}$, Michael Bauer ${ }^{2}$, and Jennifer Jensen ${ }^{3}$
}

AdDitionAl INDEX wORDs. Abies lasiocarpa var. arizonica, A. lasiocarpa var. lasiocarpa, provenance, seed source

SUMmARY. Trees from six corkbark fir (Abies lasiocarpa var. arizonica) and 10 subalpine fir ( $A$. lasiocarpa var. lasiocarpa) seed sources were grown at the University of Idaho Sandpoint Research and Extension Center (SREC), Sandpoint, ID, and two commercial nurseries in Idaho and Oregon. Posttransplant mortality was highest during the first two years. After six growing seasons, survival averaged $76 \%$ and $80 \%$ for corkbark and subalpine fir, respectively. In SREC irrigated plots, survival averaged $96 \%$ and $99 \%$ for corkbark and subalpine fir, respectively. Spring frost damage occurred annually on $66 \%$ to $100 \%$ of trees during $2002-06$. In SREC plots, damage was minor and did not adversely affect appearance. Tree heights and growth rates varied significantly between seed sources. In general, corkbark fir grew faster than subalpine fir. After nine years in the field, mean heights of SREC-grown corkbark trees ranged from 2.1 to $2.9 \mathrm{~m}$ and that of subalpine trees ranged from 1.3 to $2.3 \mathrm{~m}$, depending on seed source. Corkbark fir proved moderately resistant to resistant to a phoma-type fungal blight. Three corkbark seed sources appeared suitable for Christmas tree production. Subalpine trees were more susceptible to the blight. Some trees within both botanical varieties proved resistant to or highly tolerant of the blight, but the use of seedlings for landscapes may be unacceptably risky because of disease potential. Two fungicide programs (three applications of pyraclostrobin plus boscalid or one application of pyraclostrobin plus boscalid followed by one application of chlorothalonil) controlled the blight. Eight subalpine fir and 23 corkbark fir at SREC were selected for further testing as possible cultivars. Neither crop is recommended for sites with frequent or severe spring frosts.

$\mathrm{C}$ orkbark fir and subalpine fir have potential as landscape and Christmas trees. Desirable characteristics include soft, fragrant, green or blue-green foliage with narrow, conical habits and good winterhardiness. Subalpine fir is distributed from Arizona and New Mexico to the Yukon and Alaska, from sea level to

We thank the Idaho State Department of Agriculture Nursery and Florists Committee and the University of Idaho for funding this project, and Paradise and PossAbilities Tree Farms for participating in growing and evaluating the trees.

Mention of trade names or commercial products in this article is solely for the purpose of providing specific information and does not imply recommendation or endorsement by the U.S. Department of Agriculture. Mention of a trademark, proprietary product, or vendor does not constitute a guarantee or warranty of the product by the Idaho Agricultural Experiment Station and does not imply its approval to the exclusion of other products or vendors that also may be suitable.

${ }^{1}$ USDA ARS North Central Regional Plant Introduction Station, Iowa State University, Room G212 Agronomy Hall, Ames, IA 5001

${ }^{2}$ University of Idaho, Bonner County Extension, 4205 North Boyer Avenue, Sandpoint, ID 83864

${ }^{3}$ University of Idaho, Boundary County Extension, 6447 Kootenai, Bonners Ferry, ID 83805

${ }^{4}$ Corresponding author. E-mail: danny.barney@ars. usda.gov. more than $12,000-\mathrm{ft}$ elevation, and grows in the coolest and wettest forests of the western United States. Corkbark fir is distinguished by its peculiar, whitish, corky bark and blue-green foliage and is found mixed with subalpine fir on scattered mountains in southwestern Colorado; northern, western, and southwestern New Mexico; and in the high mountains of Arizona(Alexander et al., 1990). In the wild, corkbark and subalpine fir form stunted shrubs at timberline and average heights in closed forest conditions range from 45 to $100 \mathrm{ft}$ (Sudworth, 1916). Corkbark and subalpine fir characteristically break dormancy early in spring, and buds and new shoots can be injured by frosts. Subalpine fir adapts to a range of soil types, although growth is reported to be poor on shallow and coarse-textured soils.

Jones and Cregg (2006) hypothesized that subalpine fir is more adaptable to higher $\mathrm{pH}$ soils $(\geq 6.0)$ and drought conditions than previously thought, but considered subalpine and corkbark fir risky choices for midwestern U.S. landscapes because of limited drought tolerance and earlyemerging, frost-susceptible shoots in spring. Dirr (1998) mentions subalpine fir's limited adaptability.

Previous work at the University of Idaho suggested that subalpine fir provenances differed in growth rate, tree shape, and adaptability to cultivation (D.L. Barney, unpublished data). Corkbark fir, subalpine fir, or both from North American seed sources have been tested for Christmas tree production in Norway, Iceland, and Denmark. In Danish provenance trials, Nielsen et al. (2012) observed significant differences in tree performance between provenances and reported the best overall source was from the White River area of British Columbia, Canada. Corkbark fir from Arizona and New Mexico seed sources showed good potential but proved highly susceptible to dieback, possibly due to a Neonectria pathogen. The trees exhibited slow growth rates and the trials produced a low percentage of marketable Christmas trees after 10 years.

Our objectives were to compare survival, frost susceptibility, growth rates, total growth, tree shapes, disease resistance, and suitability for landscape and Christmas tree production for a range of subalpine and corkbark fir provenances, and to select promising genotypes for testing as possible cultivars for clonally propagated nursery stock.

\section{Materials and methods}

Seeds collected from the wild in 15 national forests of the southwestern

\begin{tabular}{llll}
\hline $\begin{array}{l}\text { Units } \\
\text { To convert U.S. to SI, } \\
\text { multiply by }\end{array}$ & U.S. unit & SI unit & $\begin{array}{l}\text { To convert SI to U.S., } \\
\text { multiply by }\end{array}$ \\
\hline 0.3048 & $\mathrm{ft}$ & $\mathrm{m}$ & 3.2808 \\
2.54 & inch(es) & $\mathrm{cm}$ & 0.3937 \\
16.3871 & inch & $\mathrm{cm}^{3}$ & 0.0610 \\
1.1209 & $\mathrm{lb} / \mathrm{acre}$ & $\mathrm{kg} \cdot \mathrm{ha}^{-1}$ & 0.8922 \\
1.6093 & mile $(\mathrm{s})$ & $\mathrm{km}$ & 0.6214 \\
70.0532 & Oz/acre & $\mathrm{g} \cdot \mathrm{ha}^{-1}$ & 0.0143 \\
$\left({ }^{\circ} \mathrm{F}-32\right) \div 1.8$ & ${ }^{\circ} \mathrm{F}$ & ${ }^{\circ} \mathrm{C}$ & $\left({ }^{\circ} \mathrm{C} \times 1.8\right)+32$
\end{tabular}


United States were provided by the Dean Swift Seed Co. (Alamosa, CO). The seeds represented six sources for corkbark fir and 10 sources for subalpine fir. The exact locations of the collection sites are proprietary and the sources are referred to only by the name of the national forests from which they were collected. The seeds were sown in Spring 1998 at the University of Idaho Forest Research Nursery in plastic foam block containers with 45 cells per block and a cell volume of $336 \mathrm{~cm}^{3}$. In Spring 2000, the plug-2 seedlings (two years in containers) were culled to remove any that had developed less than $2.5 \mathrm{~cm}$ of shoot growth during the two years in the containers and were transplanted to raised nursery beds at the University of Idaho SREC in Bonner County, ID. In Spring 2001, the seedlings were dug and sorted to remove those substantially below average size for their respective seed source or with poorly formed roots or tops. The trees were planted at SREC in replicated field plots using a randomized completeblock design containing one subplot of 20 trees for each seed source in each of the three blocks, making a total of 360 corkbark fir and 600 subalpine fir at SREC with 60 trees, total, for each seed source. Trees were spaced $6 \mathrm{ft}$ apart in rows $6 \mathrm{ft}$ apart with 12 -ft-wide alleys separating subplots.

Plots at SREC were established on moderately drained Mission silt loam soil. The location was $48.292^{\circ} \mathrm{N}$ latitude, $116.354^{\circ} \mathrm{W}$ longitude, and $2116-\mathrm{ft}$ elevation. The site averaged 33.13 inches of precipitation annually with 88.1 inches of snow. The site received an average of 4.19 inches of rainfall during July-September. The last average spring frost date $\left(32^{\circ} \mathrm{F}\right)$ was 18 May and first average fall frost date was 16 Sept. The 2012 U.S. Department of Agriculture (USDA) Plant Hardiness Zone Map lists the site as zone $6 a\left(-5\right.$ to $-10{ }^{\circ} \mathrm{F}$ average annual minimum temperature).

Grower planted and maintained nonrandomized plots were similarly established at PossAbilities Tree Farm in Bonner County, ID $(21 \mathrm{~km}$ north of SREC, lat. $48.469^{\circ} \mathrm{N}$, long. $116.435^{\circ} \mathrm{W}$, elevation $2300 \mathrm{ft}$ ), and Paradise Tree Farm in Wallowa County, OR $(269 \mathrm{~km}$ south-southwest of SREC, lat. $45.945^{\circ} \mathrm{N}$, long. $117.194^{\circ} \mathrm{W}$, elevation $4200 \mathrm{ft}$ ). Soil and climate conditions at the PossAbilities Tree Farm were similar to those at SREC, with slightly better soil drainage. The Paradise Tree Farm site was located on a well-drained Albee-Bocker complex silt loam soil. The estimated precipitation was $\approx 20.4$ inches annually with $\approx 51$ inches of annual snowfall. The USDA Plant Hardiness Zone for the Oregon site was $6 \mathrm{~b}$ $\left(0\right.$ to $-5^{\circ} \mathrm{F}$ average annual minimum temperature). Average spring and fall frost dates were $\approx 12$ June and 5 Sept., respectively.

Tree spacing at the commercial nurseries was $\approx 6 \mathrm{ft}$ between trees within rows with rows $6 \mathrm{ft}$ apart. All trees for individual seed source were planted together in one to several rows and subplots were not used. At Paradise Tree Farm, there were 1859 trees per seed source with 190 total corkbark trees and 20-48 trees per seed source or 291 total subalpine fir. At PossAbilities Tree Farm, there were 19-60 trees per seed source with 193 total corkbark trees and 20-49 trees per seed source or 289 total subalpine fir.

Trees at SREC were irrigated twice each July and twice each August, with $\approx 8$ inches of total irrigation water applied annually from 2001 to 2006. Trees in the commercial nurseries were unirrigated. Weed control consisted of a combination of mechanical and hand cultivation and preemergence and contact herbicides for each of the sites, with practices and materials varying between sites, according to standard management practices for each farm. Weed control was excellent at all sites and weed pressure did not appear to be a factor in tree survival or growth. Fertilizer practices varied between farms. At SREC, trees were fertilized in autumn from 2002 to 2006 using a slow-release isobutydine diurea $18 \mathrm{~N}-$ $2.2 \mathrm{P}-8.3 \mathrm{~K}$ analysis fertilizer. Rates ranged from $29 \mathrm{lb} /$ acre of actual nitrogen in 2002 to $60 \mathrm{lb} /$ acre in 2006 .

The percentage of surviving trees for each of the seed sources was determined each spring during 2002 06 for SREC and PossAbilities Tree Farm. Because of the remoteness of the site and unexpected travel budget limitations, survival and growth data were collected for the Paradise Tree Farm only during 2004-06.

Tree heights from the soil surface to the tips of the leaders were measured during Spring 2001 for all sites. Each autumn after growth stopped during 2001-06, each tree was measured for height from the ground to the tip of the leader and for current-season leader growth. The project was originally planned to end by the end of 2006, but the opportunity presented itself to measure SREC trees again during Autumn 2009. During 2006 and 2009 , the widths at the widest points of SREC trees, perpendicular to the trunks, were also determined to calculate a height to width index by dividing height by width. An index of 1.0 describes a tree as tall as it is wide. An index of 2.0 describes a tree twice as tall as it is wide.

During 2004-06, budbreak dates were recorded for five randomly selected trees per subplot (15 trees per seed source) at SREC. The same trees were sampled each year. Initial budbreak refers to the first open bud observed for a particular provenance. Final budbreak refers to all trees for a particular provenance having at least one open bud. Each tree at SREC was examined in mid spring from 2002 to 2006 to record whether frost damage had occurred that year.

Each SREC tree was rated for visual foliar blight symptoms on a 1 to 6 scale during 2008 and 2009 in response to symptoms that first appeared in 2007 at SREC and a nearby Christmas tree farm. A rating of 1 indicates no visual symptoms. Ratings of 2-6 indicate $<10 \%, 10 \%$ to $24 \%, 25 \%$ to $49 \%$, $50 \%$ to $74 \%$, or $75 \%$ to $100 \%$ of the foliage exhibiting blight symptoms, respectively. Two fungicide treatments were tested for blight control during 2009. Pyraclostrobin plus boscalid (Pageant; BASF, Research Triangle Park, NC) was applied to one block at $2.05 \mathrm{oz} /$ acre pyraclostrobin plus $4.03 \mathrm{oz} /$ acre boscalid on $21 \mathrm{May}$, 9 June, and 26 June. The same fungicide was applied to a second block at the same rate on 21 May, followed by an application of $2.48 \mathrm{lb} /$ acre chlorothalonil (Bravo Weather Stik; Syngenta Crop Protection, Greensboro, $\mathrm{NC})$ on 10 June. The rates used were within the label rates for these products. Although the label rate for chlorothalonil for phoma twig blight was 1.125 to $2.1 \mathrm{lb} /$ acre, the tentative diagnosis of phoma-type fungal blight was not made until Aug. 2010. At the time of application, we were dealing with an unidentified fungal pathogen and chose to use a moderately high rate of chlorothalonil within the rates allowed for conifer diseases. The third 
block served as the control and received no fungicide treatments.

During Summer 2006, six owners and operators of commercial landscape nurseries and Christmas tree farms and the senior author evaluated all of the trees at SREC for potential as cultivars for clonally propagated nursery stock. The selections were based on tree height and subjective impressions involving tree shape, distribution of branches and foliage, foliar fullness and texture, needle length, and needle color. Selected trees were observed during 2007-09 and final selections were made in Autumn 2009, adding resistance or tolerance to foliar blight as a selection criterion.

Although the USDA has published standards for grades of Christmas trees (USDA, 1989), corkbark and subalpine fir are not mentioned in that publication. We also did not shear or otherwise prune the trees to develop high-density foliage and fill in defects with new growth, as is normally done for commercial Christmas tree production. We chose, instead, to allow the trees to develop their natural shapes for evaluation purposes, although multiple leaders were removed to form one straight trunk per tree. For these reasons, we did not grade the trees using USDA Christmas tree standards.

Tree heights, leader lengths, height to width indices, and disease susceptibility for SREC-grown trees (randomized and replicated plots) were evaluated using analysis of variance [ANOVA (Systat version 13; Systat Software, San Jose, CA)]. Each year (2001, 2008, and 2009) and each botanical variety (corkbark and subalpine fir) were analyzed separately, except that when all corkbark fir were compared with all subalpine fir, botanical variety became an independent variable. When dealing with botanical varieties separately, seed source became the independent variable. Interactions between botanical variety and seed source were not investigated. Categorical disease ratings were transformed using square roots (Gomez and Gomez, 1984) before ANOVA. Treatment means were separated using the Tukey range test $(\alpha=0.05)$.

\section{Results and discussion}

Mortality was relatively high at Paradise Tree Farm during the first two to three years (Table 1 ), with $43 \%$ of corkbark and $63 \%$ of subalpine trees surviving as of 2006. According to the owner, gopher damage may have caused much of the mortality. Corkbark fir survival at PossAbilities Tree Farm (89\%) was actually higher than it appears in Table 1. Planting stock for the Santa Fe seed source suffered damage during preplant storage and transport. Excluding this seed source for the PossAbilities site resulted in average corkbark survival of $97 \%$, similar to that at the irrigated SREC plots $(96 \%)$. Subalpine fir survival was greater at SREC (99\%) than for any of the other sites.

During 2004, corkbark and subalpine trees began breaking bud on the same day. During 2005 and 2006, subalpine trees began breaking bud 3 and $4 \mathrm{~d}$ earlier, respectively, than corkbark trees. Although the differences were statistically significant $(P \leq 0.029)$, the corresponding mean budbreak dates for the two botanical varieties across the three years differed by less than $1.5 \mathrm{~d}$ (Table 2). Within years, differences in mean budbreak between corkbark fir seed sources were significant in 2005 and 2006. For subalpine seed sources, the differences in mean budbreak date were significant during all three years. In general, trees from the corkbark seed source Coronado sometimes broke earlier than other seed sources. For subalpine fir, trees derived from the Dixie, Kaibab, and Uncompahgre National Forests tended to break bud later than those from other seed sources.

As suggested by Jones and Cregg (2006), the fir seedlings proved susceptible to spring frosts, with $66 \%$ to
$100 \%$ and $74 \%$ to $100 \%$ of corkbark and subalpine trees, respectively, exhibiting frost damage during 2002-06 at SREC (Table 3). Frost injury percentages were similar at the commercial nurseries (data not shown). Frost damage at SREC was confined to relatively few lateral shoots per tree and appeared to have little or no impact on leader buds or growth. Visual damage associated with frost injury appeared to be more severe at PossAbilities Tree Farm. Frost damage to newly emerged shoots $(\approx \leq \mathrm{l} \mathrm{cm} \mathrm{long})$ and nearly open buds at SREC appeared to correlate with a daily minimum air temperature of $\approx 29^{\circ} \mathrm{F}$ or less, as recorded at the U.S. National Weather Service weather station located $100 \mathrm{~m}$ from the fir plots.

As plug-2-1 liner stock (two years in containers and one year in a transplant bed), corkbark fir seedlings were taller than subalpine seedlings. Mean heights aboveground after planting for all sites was 20.8 and $15.4 \mathrm{~cm}$, respectively, for corkbark and subalpine fir, with the difference being statistically significant $(P \leq 0.001)$ (Table 4$)$.

After six growing seasons, corkbark and subalpine fir trees at SREC averaged 114 and $81 \mathrm{~cm}$ of total leader growth, respectively (Fig. 1). Corresponding trees at Paradise Tree Farm averaged 93 and $65 \mathrm{~cm}$ and those at PossAbilities Tree Farm averaged 90 and $42 \mathrm{~cm}$, respectively, for corresponding provenances

After nine growing seasons at SREC, the corkbark trees remained significantly taller than subalpine trees $(P \leq 0.020)$, with mean heights of 2.45 and $1.72 \mathrm{~m}$, respectively

Table 1. Survival percentages of corkbark and subalpine fir trees at PossAbilities Tree Farm and the University of Idaho Sandpoint Research and Extension Center (SREC) in Bonner County, ID, and Paradise Tree Farm in Wallowa County, OR. Trees were planted in May through June 2001. Survival was evaluated in spring during 2002-06.

\begin{tabular}{lccccc}
\hline & \multicolumn{5}{c}{ Trees surviving (\%) } \\
\cline { 2 - 6 } Site & $\mathbf{2 0 0 2}$ & $\mathbf{2 0 0 3}$ & $\mathbf{2 0 0 4}$ & $\mathbf{2 0 0 5}$ & $\mathbf{2 0 0 6}$ \\
\hline Corkbark fir $^{\text {Paradise }}$ & & & & & \\
PossAbilities & & - & 43.0 & 43.0 & 43.0 \\
SREC & 90.2 & 88.8 & 88.8 & 88.6 & 88.3 \\
Mean & 96.4 & 96.4 & 96.4 & 96.4 & 96.4 \\
Subalpine fir $_{\text {Paradise }}^{\mathrm{z}}$ & - & - & 76.1 & 76.0 & 75.9 \\
PossAbilities & - & - & 63.1 & 63.1 & 63.1 \\
SREC & 83.1 & 81.7 & 81.1 & 80.2 & 78.5 \\
Mean & 99.0 & 98.7 & 98.5 & 98.5 & 98.5 \\
\hline
\end{tabular}

${ }^{2}$ Because of the remote location and travel limitations, trees were not evaluated in 2002 and 2003 .

${ }^{y}$ Most corkbark fir losses were in the Santa Fe seed source and probably due to preplant injury to the trees. Excluding Santa Fe trees, corkbark survival was $97.3 \%$ after six growing seasons. 
(Table 4). Within each botanical variety, heights varied significantly between seed sources. Mean heights for Apache and Gila National Forest corkbark fir provenances averaged 2.89 and $2.83 \mathrm{~m}$, respectively. For Kaibab provenances, subalpine fir heights averaged 2.27 and $2.10 \mathrm{~m}$, respectively. In Danish Christmas tree trials (Nielsen et al., 2012), corkbark and subalpine

Table 2. Dates of budbreak for corkbark and subalpine fir at the University of Idaho Sandpoint Research and Extension Center, Sandpoint, ID. Initial budbreak refers to the first open bud. Final budbreak refers to the date when all trees for that botanical variety exhibited at least one open bud.

\begin{tabular}{llll}
\hline & \multicolumn{3}{c}{$\begin{array}{c}\text { Date of budbreak } \\
\text { (day of yr) }\end{array}$} \\
\cline { 2 - 5 } & $\mathbf{2 0 0 4}$ & $\mathbf{2 0 0 5}$ & $\mathbf{2 0 0 6}$ \\
\hline Corkbark fir & & & \\
$\quad$ Initial budbreak & 103 & 101 & 110 \\
Final budbreak & 107 & 114 & 120 \\
Mean & 103.9 & 110.0 & 114.6 \\
Subalpine fir & & & \\
Initial budbreak & 103 & 98 & 106 \\
$\quad$ Final budbreak & 114 & 114 & 118 \\
Mean & 104.4 & 108.6 & 113.2 \\
\hline
\end{tabular}

${ }^{2}$ Date of budbreak = cumulative day of the year (i.e., 1 = 1 Jan., $365=31$ Dec.). and Uncompahgre National Forest

tree heights after 10 years in the field were $\approx 2 \mathrm{~m}$.

The widths of the trees at the widest points were also significantly greater for corkbark than subalpine trees $(P \leq 0.000)$ after nine years in the field, averaging 1.35 and $1.09 \mathrm{~m}$, respectively (Table 4 ). The index of tree heights to widths were greater for corkbark trees than subalpine trees $(P \leq 0.000)$ with mean values of 1.88 and 1.58 , respectively, quantifying the characteristic that corkbark trees typically developed slightly narrower profiles than did subalpine trees during their first nine years in the field (Table 4).

Foliar blight symptoms were first observed in 2007 at SREC (eight growing seasons from initial transplanting) and a Christmas tree farm $\approx 3 \mathrm{~km}$ away. Symptoms occurred primarily on newly developed lateral shoots in early-mid June during 200709. Affected shoots developed brown, necrotic areas on the needles and stems, with entire shoots eventually becoming necrotic. Many needles fell from the shoots by late summer. Some dead shoots and needles remained on the trees from one season to the next. Symptoms at SREC typically began and remained most concentrated in the lower two-thirds of the trees. During

Table 3. Frost damage observed on corkbark and subalpine fir grown at the University of Idaho Sandpoint Research and Extension Center in Bonner County, ID. Trees were examined yearly after the last frost dates. Figures in the columns represent the percentages of trees for that seed source showing one or more frost-damaged buds or shoots.

\begin{tabular}{lccccc}
\hline & \multicolumn{5}{c}{ Trees exhibiting frost damage (\%) } \\
\cline { 2 - 6 } Seed source (National Forest) & $\mathbf{2 0 0 2}$ & $\mathbf{2 0 0 3}$ & $\mathbf{2 0 0 4}$ & $\mathbf{2 0 0 5}$ & $\mathbf{2 0 0 6}$ \\
\hline Corkbark fir & & & & & \\
$\quad$ Apache-Sitgreaves & 53.3 & 100 & 96.6 & 78.0 & 100 \\
Cibola & 60.0 & 100 & 81.4 & 69.5 & 100 \\
Coconino & 66.7 & 100 & 91.4 & 79.3 & 100 \\
Coronado & 75.0 & 100 & 94.8 & 81.0 & 100 \\
Gila & 81.7 & 100 & 100 & 76.8 & 96.4 \\
Santa Fe & 56.7 & 100 & 89.5 & 61.4 & 98.2 \\
Mean & 65.6 & 100 & 92.3 & 74.3 & 99.1 \\
Subalpine fir & & & & & \\
Arapaho & 91.7 & 100 & 81.0 & 86.4 & 100 \\
Carson & 86.7 & 100 & 83.3 & 83.3 & 100 \\
Cibola & 93.3 & 100 & 98.3 & 74.1 & 100 \\
Dixie & 55.0 & 100 & 57.6 & 44.1 & 100 \\
Kaibab & 38.3 & 100 & 64.9 & 61.4 & 100 \\
Manti-La Sal & 71.7 & 100 & 60.3 & 75.9 & 100 \\
Rio Grande & 96.7 & 100 & 93.3 & 81.7 & 98.3 \\
San Isabel & 88.3 & 100 & 98.1 & 88.9 & 100 \\
San Juan & 98.3 & 98 & 95.0 & 88.3 & 100 \\
Uncompahgre & 48.3 & 100 & 82.3 & 51.7 & 100 \\
Mean & 76.8 & 99.8 & 81.4 & 73.6 & 99.8 \\
\hline
\end{tabular}

the three years of observation, blight symptoms seldom appeared on leaders. There did not appear to be any causal relationship between frost injury and fungal blight. Frost-damaged shoots were killed abruptly, usually during early to mid May when they were $1-\mathrm{cm}$ long or less. Blight symptoms usually appeared in early to mid June on otherwise healthy-appearing lateral shoots $\approx 5-12$-cm long.

Although the pathogen was clearly a fungus, it has not yet been positively identified. Tests at the Washington State University Plant and Insect Diagnostic Laboratory in Puyallup during 2010 showed good homology to Phoma isolates. Although the blight appears to be due to a primary pathogen, rather than a secondary fungus, further work is needed to identify the pathogenic organism.

On average, corkbark fir showed significantly fewer disease symptoms than did subalpine fir $(P \leq 0.002)$, with mean visual ratings of 2.0 and 2.3 , respectively, for all three blocks in 2008 and 2.0 and 2.8 , respectively, for control blocks in 2009. We observed no significant differences between the six corkbark fir seed sources in terms of symptoms (Table 5). Symptoms varied significantly between subalpine fir seed sources during 2008 and 2009, with means ranging from 1.2 to 3.3 in 2008 and 1.2 to 4.9 in 2009. Of the five fastest growing subalpine seed sources, four were highly susceptible to the foliar blight. Trees receiving ratings of 1 or 2 were considered marketable for either landscape nursery stock or Christmas trees. Trees with ratings greater than 2 were considered unmarketable.

Both fungicide treatments (three biweekly applications of pyraclostrobin plus boscalid or one application of pyraclostrobin plus boscalid followed by one application of chlorothalonil) significantly reduced foliar blight symptoms in corkbark $(P \leq 0.000)$ and subalpine fir $(P \leq 0.000)$ compared with untreated trees (Table 5 ). Visual disease symptom ratings for trees within the two fungicide treatments did not differ significantly for either corkbark or subalpine trees. During $2009,78 \%$ of untreated corkbark fir, $52 \%$ of untreated subalpine fir, and $100 \%$ of fungicide-treated corkbark and subalpine fir trees received foliar blight ratings of 1 or 2 . Readers should note that the fungicide results are based 
Table 4. Tree heights at the time of planting (2001) and tree heights, widths at the widest points, and indices of height to width of corkbark and subalpine fir trees after nine growing seasons (2009) at the University of Idaho Sandpoint Research and Extension Center. Tree widths were not measured in 2001.

\begin{tabular}{|c|c|c|c|c|}
\hline \multirow[b]{2}{*}{$\begin{array}{l}\text { Seed source } \\
\text { (National Forest) }\end{array}$} & 2001 & 2009 & 2009 & 2009 \\
\hline & $\mathrm{Ht}(\mathrm{cm})^{\mathrm{z}}$ & $\mathrm{Ht}(\mathrm{cm})^{\mathrm{y}}$ & Width $(\mathrm{cm})$ & $\begin{array}{l}\text { Ht to width index } \\
\left(\mathrm{m} \cdot \mathrm{m}^{-1}\right)^{\mathrm{x}}\end{array}$ \\
\hline \multicolumn{5}{|l|}{ Corkbark fir } \\
\hline Apache-Sitgreaves & $25.4 \mathrm{a}^{\mathrm{w}}$ & $288.9 \mathrm{a}$ & $145.9 \mathrm{a}$ & $1.98 \mathrm{a}$ \\
\hline Cibola & $21.1 \mathrm{~b}$ & $230.6 \mathrm{bc}$ & $141.5 \mathrm{ab}$ & $1.64 \mathrm{a}$ \\
\hline Coconino & $18.8 \mathrm{c}$ & $238.0 \mathrm{~b}$ & $131.7 \mathrm{bcd}$ & $1.83 \mathrm{a}$ \\
\hline Coronado & $19.2 \mathrm{bc}$ & $222.7 \mathrm{bc}$ & $125.9 \mathrm{~d}$ & $2.09 \mathrm{a}$ \\
\hline Gila & $26.0 \mathrm{a}$ & $282.9 \mathrm{a}$ & $137.6 \mathrm{abc}$ & $2.07 \mathrm{a}$ \\
\hline Santa Fe & $20.2 \mathrm{bc}$ & $207.6 \mathrm{c}$ & $127.0 \mathrm{~cd}$ & $1.64 \mathrm{a}$ \\
\hline Mean & 21.8 & 245.1 & 134.9 & $1.88 \mathrm{a}$ \\
\hline \multicolumn{5}{|l|}{ Subalpine fir } \\
\hline Arapaho & 15.4 defx & $139.7 \mathrm{ef}$ & $93.7 \mathrm{~d}$ & $1.49 \mathrm{de}$ \\
\hline Carson & 16.5 bcde & $155.5 \mathrm{de}$ & $116.4 \mathrm{~b}$ & $1.33 \mathrm{e}$ \\
\hline Cibola & $15.1 \mathrm{ef}$ & $186.1 \mathrm{bc}$ & $119.7 \mathrm{~b}$ & $1.57 \mathrm{bcd}$ \\
\hline Dixie & $17.6 \mathrm{bc}$ & $198.6 \mathrm{~b}$ & $111.4 \mathrm{bc}$ & $1.80 \mathrm{a}$ \\
\hline Kaibab & $21.1 \mathrm{a}$ & $227.3 \mathrm{a}$ & $131.6 \mathrm{a}$ & $1.74 \mathrm{ab}$ \\
\hline Manti-La Sal & $17.4 \mathrm{bcd}$ & $164.8 \mathrm{~cd}$ & $99.5 \mathrm{~d}$ & $1.67 \mathrm{abc}$ \\
\hline Rio Grande & $14.5 \mathrm{ef}$ & $149.6 \mathrm{def}$ & $99.1 \mathrm{~d}$ & $1.50 \mathrm{cde}$ \\
\hline San Isabel & $13.5 \mathrm{f}$ & $130.7 \mathrm{f}$ & $99.4 \mathrm{~d}$ & $1.32 \mathrm{e}$ \\
\hline San Juan & $15.5 \mathrm{cdef}$ & $157.3 \mathrm{de}$ & $101.5 \mathrm{~cd}$ & $1.57 \mathrm{bcd}$ \\
\hline Uncompahgre & $18.4 \mathrm{~b}$ & $209.5 \mathrm{ab}$ & $119.5 \mathrm{~b}$ & $1.77 \mathrm{a}$ \\
\hline Mean & 16.5 & 171.9 & 109.2 & 1.58 \\
\hline
\end{tabular}

${ }^{\mathrm{z}} 1 \mathrm{~cm}=0.3937$ inch.

y2009 height represents means for all trees for a particular seed source. One-third of corkbark and subalpine trees did not receive fungicide treatments in 2009 and their leader growth was significantly less than for fungicidetreated trees during that year.

${ }^{x}$ Height to width index $=$ tree height $/$ tree width; $1 \mathrm{~m}=3.2808 \mathrm{ft}$.

${ }^{\mathrm{w}}$ Means within a column not followed by the same letter are significantly different based on the Tukey range test $(\alpha=0.05)$. Corkbark and subalpine fir are treated separately.

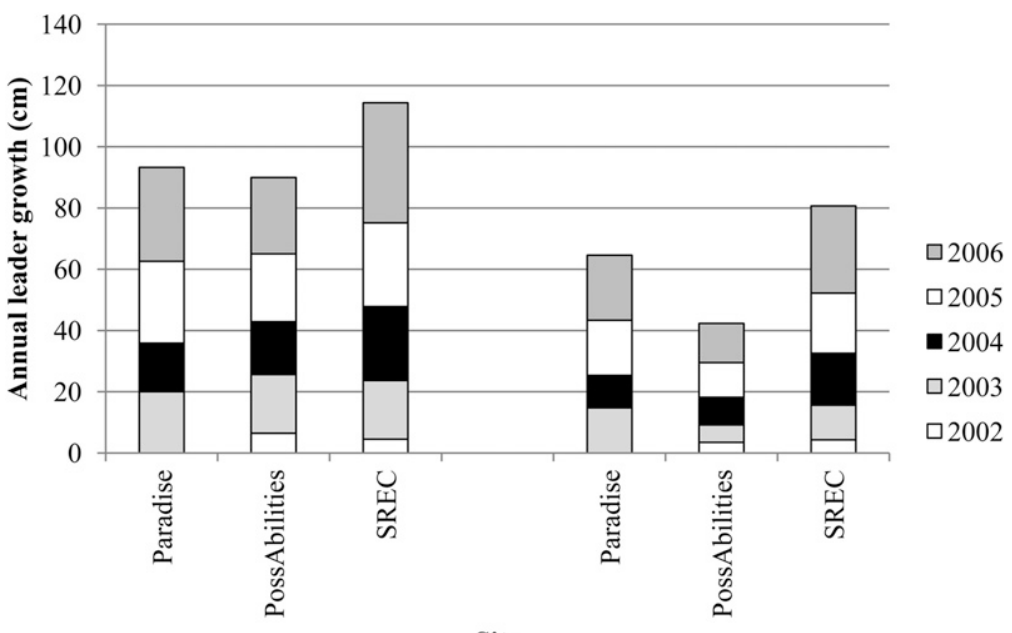

Site

Fig. 1. Mean annual leader growth of corkbark (left) and subalpine (right) fir trees at Paradise Tree Farm, Wallowa County, OR, and PossAbilities Tree Farm and the University of Idaho Sandpoint Research and Extension Center (SREC), Bonner County, ID, for 2002-06. Trees were planted as plug-2-1 seedlings in 2001 (two years in containers and one year in a transplant bed) and developed little or no leader growth during 2001. Leader growth data were not measured at Paradise Tree Farm during 2002-03. The 2003 bar for that nursery represents total leader growth during 2001-03, as measured during 2004; $1 \mathrm{~cm}=0.3937$ inch.

on a single season of application and limited replications. Further trials were impossible because of closure of SREC.
Although visible blight symptoms were generally not observed on leaders, the blight appeared to affect leader growth in 2009. For corkbark fir, leader growth on control trees was significantly less than that for trees in either fungicide treatment $(P \leq 0.028$ and $P \leq 0.013$ ). Control subalpine fir developed significantly less leader growth than trees in either fungicide treatment $(P \leq 0.003$ and $P \leq 0.000)$. Widths of control trees for corkbark and subalpine seed sources did not differ significantly from trees in fungicide treatments in 2009

During 2006, 93 of the 960 trees planted at SREC were selected for clonal evaluations. Foliar blight affected many of these trees beginning in 2007. During 2009, 31 of these trees were selected for cooperator testing, based on the previous standards and foliar blight resistance or tolerance. Of the 31 trees selected, 23 were corkbark fir. The Apache-Sitgreaves National Forest seed source produced the highest percentage of selected trees, followed by Coconino and Gila $\mathrm{Na}$ tional Forests (Fig. 2).

\section{Conclusion}

In irrigated plots at SREC, seedling survival was high, averaging 96\% and $99 \%$ for corkbark and subalpine fir, respectively. Survival of corkbark fir at one unirrigated nursery averaged $97 \%$ for five of the six corkbark fir seed sources tested. Subalpine fir at the same nursery averaged $79 \%$ survival for nine seed sources. Nearly all mortality occurred during the first two to three years in the fields. Leader growth was greater in irrigated plots at SREC than at unirrigated nurseries. Because the experiment was not designed to test the effects of irrigation, no cause and effect can be determined for survival or leader growth rates. However, our results combined with the observation by Alexander et al. (1990) that this species is found in the wettest forests within its range suggest further studies on irrigation may be warranted.

All seed sources at all sites proved highly susceptible to frost damage (data shown only for SREC). At SREC, frost damage was typically minor and had little apparent effect on leader growth or overall tree appearance. Damage was more extensive at a nearby commercial nursery. Both corkbark and subalpine trees broke bud at about the same time, with subalpine fir sometimes breaking bud as much as $4 \mathrm{~d}$ earlier than corkbark fir. Within botanical varieties, some seed sources consistently broke bud earlier 
Table 5. Severity of Phoma-type fungal blight symptoms on corkbark and subalpine fir trees after eight and nine growing seasons in nursery plots at the University of Idaho Sandpoint Research and Extension Center. Values represent means for 17-20 trees of each seed source. Values for 2008 were determined for the same trees as those in 2009 control plots not treated with fungicides.

\begin{tabular}{|c|c|c|c|c|}
\hline \multirow[b]{3}{*}{ Seed source (National Forest) } & \multicolumn{4}{|c|}{ Blight severity $(1-6 \text { scale })^{\mathrm{z}}$} \\
\hline & & 2009 & 2009 & 2009 \\
\hline & 2008 & Control & Fungicide $1^{y}$ & Fungicide $2^{\mathrm{x}}$ \\
\hline \multicolumn{5}{|l|}{ Corkbark fir } \\
\hline Apache-Sitgreaves & $1.90 \mathrm{a}^{\mathrm{w}}$ & $2.00 \mathrm{a}$ & $1.50 \mathrm{ab}$ & $1.65 \mathrm{a}$ \\
\hline Cibola & $2.10 \mathrm{a}$ & $2.15 \mathrm{a}$ & $1.84 \mathrm{a}$ & $1.30 \mathrm{a}$ \\
\hline Coconino & $1.79 \mathrm{a}$ & $1.89 \mathrm{a}$ & $1.63 \mathrm{ab}$ & $1.30 \mathrm{a}$ \\
\hline Coronado & $1.80 \mathrm{a}$ & $1.80 \mathrm{a}$ & $1.67 \mathrm{ab}$ & $1.40 \mathrm{a}$ \\
\hline Gila & $2.37 \mathrm{a}$ & $2.32 \mathrm{a}$ & $1.65 \mathrm{ab}$ & $1.35 \mathrm{a}$ \\
\hline Santa Fe & $1.95 \mathrm{a}$ & $2.05 \mathrm{a}$ & $1.25 \mathrm{~b}$ & $1.39 \mathrm{a}$ \\
\hline Mean & 1.99 & 2.04 & 1.59 & 1.40 \\
\hline \multicolumn{5}{|l|}{ Subalpine fir } \\
\hline Arapaho & $2.15 \mathrm{~b}$ & $2.60 \mathrm{~cd}$ & $1.30 \mathrm{a}$ & $1.53 \mathrm{a}$ \\
\hline Carson & $1.45 \mathrm{ab}$ & $1.20 \mathrm{a}$ & $1.35 \mathrm{a}$ & $1.35 \mathrm{a}$ \\
\hline Cibola & $1.58 \mathrm{ab}$ & $2.05 \mathrm{bc}$ & $1.70 \mathrm{a}$ & $1.37 \mathrm{a}$ \\
\hline Dixie & $3.25 \mathrm{c}$ & $4.90 \mathrm{f}$ & $1.40 \mathrm{a}$ & $1.53 \mathrm{a}$ \\
\hline Kaibab & $3.32 \mathrm{c}$ & $3.21 \mathrm{de}$ & $1.37 \mathrm{a}$ & $1.29 \mathrm{a}$ \\
\hline Manti-La Sal & $3.16 \mathrm{c}$ & $4.47 \mathrm{f}$ & $1.32 \mathrm{a}$ & $1.63 \mathrm{a}$ \\
\hline Rio Grande & $2.05 \mathrm{ab}$ & $2.25 \mathrm{c}$ & $1.45 \mathrm{a}$ & $1.45 \mathrm{a}$ \\
\hline San Isabel & $1.18 \mathrm{a}$ & $1.24 \mathrm{ab}$ & $1.33 \mathrm{a}$ & $1.50 \mathrm{a}$ \\
\hline San Juan & $2.10 \mathrm{~b}$ & $2.15 \mathrm{c}$ & $1.70 \mathrm{a}$ & $1.35 \mathrm{a}$ \\
\hline Uncompahgre & $3.20 \mathrm{c}$ & $4.20 \mathrm{ef}$ & $1.50 \mathrm{a}$ & $1.60 \mathrm{a}$ \\
\hline Mean & 2.34 & 2.83 & 1.44 & 1.46 \\
\hline
\end{tabular}

${ }^{2}$ Disease symptoms were rated on a visual estimation of the percentage of foliage affected. $\mathrm{l}=$ no visual symptoms, $2=<10 \%, 3=10 \%$ to $24 \%, 4=25 \%$ to $49 \%, 5=50 \%$ to $74 \%, 6=75 \%$ to $100 \%$.

${ }^{y}$ Fungicide $\mathrm{l}=2.05 \mathrm{oz} /$ acre pyraclostrobin plus $4.03 \mathrm{oz} /$ acre boscalid applied on $21 \mathrm{May}, 9 \mathrm{June}$, and $26 \mathrm{June}$; $1 \mathrm{oz} / \mathrm{acre}=70.0532 \mathrm{~g} \cdot \mathrm{ha}^{-1}$.

${ }^{x}$ Fungicide $2=2.05 \mathrm{oz} /$ acre pyraclostrobin plus $4.03 \mathrm{oz} /$ acre boscalid applied on 21 May, followed by 2.48 $\mathrm{lb} /$ acre chlorothalonil on $10 \mathrm{June} ; \mathrm{l} \mathrm{lb} / \mathrm{acre}=1.1209 \mathrm{~kg} \cdot \mathrm{ha}^{-1}$.

"Means within a column not followed by the same letter are significantly different based on the Tukey range test $(\alpha=0.05)$. Corkbark and subalpine fir are treated separately.

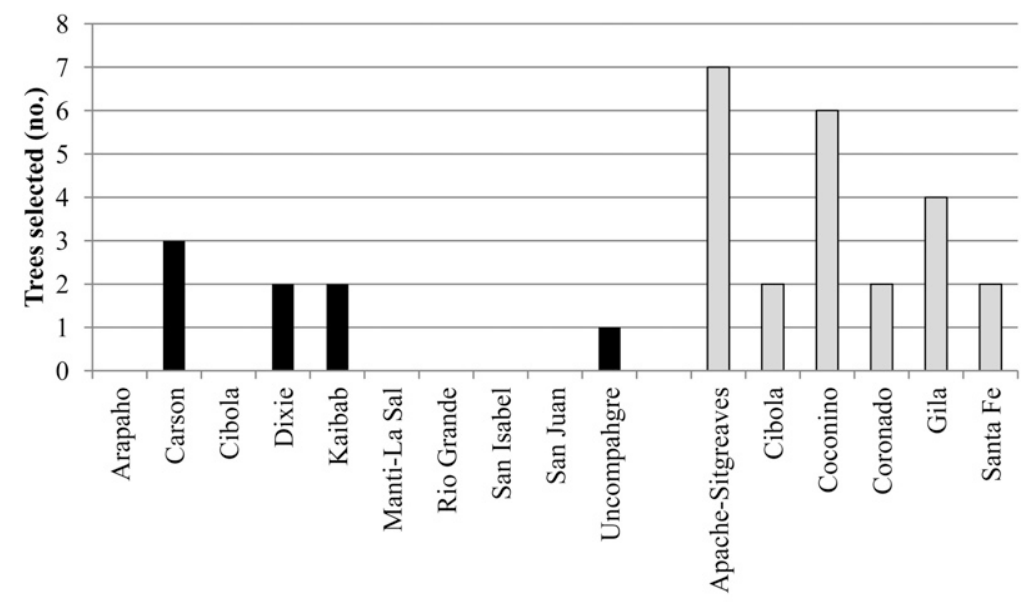

Seed Sources

Fig. 2. Distribution among seed sources of corkbark and subalpine fir trees selected at the University of Idaho Sandpoint Research and Extension Center (Bonner County, ID) in $\mathbf{2 0 0 9}$ for testing as potential cultivars. Each seed source represents the U.S. National Forest from which it was collected. Selections were made based on tree height, foliar blight resistance/tolerance, and subjective evaluations of tree shape and foliage texture, distribution, color, and needle length. Trees were planted as plug-2-1 seedlings in 2001 (two years in containers and one year in a transplant bed) and 53 to 60 trees were available for evaluation for each seed source. or later than some other seed sources, but the actual differences were minor. In related trials at SREC (D.L. Barney, unpublished data), the corkbark and subalpine fir seed sources tested broke bud as much as $14 \mathrm{~d}$ earlier than similar age colorado spruce (Picea pungens) and concolor fir (Abies concolor) trees in nearby plots. Because of early budbreak and high frost susceptibility, nursery production and landscape use on sites subject to frequent and severe late spring frosts may be questionable for the seed sources tested. This conclusion supports that of Jones and Cregg (2006) regarding site adaptability of subalpine fir.

For the provenances tested, seed source had a significant influence on annual leader growth and heights after six and nine growing seasons. In general, corkbark trees were taller than subalpine trees when they were transplanted as plug-2-1 seedlings, and continued to be taller during nine growing seasons.

Although foliar blight was easily controlled with fungicide applications, the use of subalpine fir seedlings from the sources tested appears questionable for landscapes where disease management may be limited or nonexistent. For Christmas tree farms where growers wish to grow subalpine fir and are willing to invest in fungicide applications, suggested seed sources, based on growth rates and tree appearance, include Cibola, Dixie, Kaibab, and Uncompahgre National Forests. The Cibola National Forest seed source was the most blight-tolerant subalpine fir source tested in these trials.

All of the corkbark fir provenances tested appeared suitable for Christmas tree production. Under the growing conditions similar to those at SREC, fungicide applications may not be necessary to control foliar blight on the corkbark fir seed sources tested, although heavy disease pressure significantly reduced leader growth, even when visible symptoms appeared minor. Although corkbark were more blight tolerant than the subalpine trees, landscape use of corkbark fir seedlings from the provenances tested may raise unacceptable risks. On the basis of growth rates and overall appearance, suggested corkbark fir seed sources include the Apache-Sitgreaves, Coconino, and Gila National Forests.

Within both botanical varieties, some trees in these trials appeared to 


\section{Research Reports}

be resistant to or highly tolerant of foliar blight, grew relatively rapidly, and developed attractive foliage and forms. Additional provenance collections and evaluations, and further testing of selected clonally propagated corkbark and subalpine fir selections for disease resistance, growth rate, and tree form appear warranted.

\section{Literature cited}

Alexander, R., R. Shearer, and D. Shepperd. 1990. Abies lasiocarpa (Hook) Nutt., p. 60-70. In: R. Burns and B. Honkala (eds.).
Silvics of North America. USDA Agr. Hdbk 654, Vol. 2. U.S. Dept. Agr., For. Serv., Washington, DC.

Dirr, M.A. 1998. Manual of woody landscape plants. Stipes, Champaign, IL.

Gomez, K. and A. Gomez. 1984. Statistical procedures for agricultural research. 2nd ed. Wiley, New York, NY.

Jones, G.E. and B.M. Cregg. 2006. Screening exotic firs for the midwestern United States: Interspecific variation in adaptive traits. HortScience 41:323328.
Nielsen, U.B., O.K. Hansen, and C. Bjergager. 2012. Subalpine fir (Abies lasiocarpa ssp.) provenance testing in Denmark, p. 12-18. In: C. Landgren (ed.). Proceedings 10th Intl. Christmas Tree Res. Ext. Conf. Eichgraben, Austria, 21-27 Aug. 2011.

Sudworth, G. 1916. The spruce and balsam fir trees of the Rocky Mountain region. U.S. Dept. Agr. Bul. 327.

U.S. Department of Agriculture. 1989. United States standards for grades of Christmas trees. U.S. Dept. Agr., Agr. Marketing Serv., Washington, DC. 